\section{Regulation of Bell Pepper Seedling Growth with End-of-day Supplemental Fluorescent Light}

\author{
Heather A. Hatt Graham ${ }^{1}$ and Dennis R. Decoteau ${ }^{2}$ \\ Department of Horticulture, Poole Agricultural Center, Box 340375, Clemson \\ University, Clemson, SC 29634-0375
}

Additional index words. phytochrome, Capsicum annuum, light quality

\begin{abstract}
The influence of end-of-day (EOD), supplemental, cool-white fluorescent light on pepper (Capsicum annuum L. cv. Keystone Resistant Giant No. 3) seedling growth and fruit production after transplanting to the field was investigated. Seedlings were exposed to this light source, which is high in the red wavebands, from one (1988) or two bulbs (1989) for 1 hour before the end of the natural photoperiod. Each year control plants were exposed to ambient light and received no supplemental fluorescent light. Before transplanting to the field, seedlings exposed to two bulbs were shorter and had smaller leaves than plants in the control treatment. Supplemental fluorescent light treatment, regardless of number of bulbs, reduced plant height, leaf area, fruit weight, and fruit count at the first harvest. Total fruit production was not affected by supplemental light, suggesting no residual effect of the light treatment during transplant production on total subsequent fruit production.
\end{abstract}

In the field, pepper seed germination is often erratic with low germination rates (Cochran, 1936; Randle and Honma, 1981). Therefore, commercial pepper plantings frequently are established using transplants (Cook et al., 1982). Commercial and experimental methods to control pepper transplant growth include applying plant growth regulators, regulating temperature during hardening or by controlling day and night temperatures, and inducing mechanical (seismic) stress (Carlson, 1990). Environmental concerns limit the use of some growth regulators for transplant height control (Moore, 1989), and to our knowledge, no chemical growth retardant is available to use on vegetable transplants. Growth regulation by temperature potentially is expensive because it often requires cooling day temperatures below night temperatures (Carlson, 1990), and mechanical stress requires abrasive touching or agitation of plants (Latimer, 1990). Therefore, an alternative low-cost method is needed to control vegetable transplant growth and minimize any deleterious effects to the plant, the environment, or the consumer.

\footnotetext{
Received for publication 24 June 1994. Accepted for publication 13 Jan. 1995. Technical contribution no. 3443 of the South Carolina Agricultural Expt. Station. Use of trade names does not imply endorsement of the products named nor criticism of similar ones not named. This research was supported in part by Expt. Station Project no. 1187 and U.S. Dept. of Agriculture Special Grant P.L. 89-106. No endorsement of the products named is implied by Clemson Univ. or the South Carolina Expt. Station. We thank Jim Harris, Glen Christian, and Anthony Melton for technical support. The cost of publishing this paper was defrayed in part by the payment of page charges. Under postal regulations, this paper therefore mus be hereby marked advertisement solely to indicate this fact.

${ }^{1}$ Current address: Plant Sciences Dept., New Mexico State Univ., Las Cruces, NM 88003.

${ }^{2}$ To whom reprint requests should be addressed.
}

Manipulating light quality regulates growth of tomato (Lycopersicon esculentum Mill.) (Decoteau and Friend, 1991) and bedding plants (Benson, 1992). Treatment with red (R) light or supplemental fluorescent light at the end of the day (EOD) (Decoteau and Friend, 1991) or altering the far-red (FR) $: \mathrm{R}$ ratio (FR :R) all day (Benson, 1992) reduced transplant height but did not affect yield. Subtle changes in light quality reflected from colored mulches and EOD R and FR light treatments affected bell pepper plant growth and fruit yield (Decoteau et al., 1990; Hatt et al., 1993). Based on our previous research on effect of light quality on tomato and pepper growth and development, we hypothesized that peppers are more sensitive to changes in spectral quality than tomato. Among crops, differential sensitivity to light quality may limit the commercial use of EOD light quality regulation of transplant production. Our objectives were 1) to determine if EOD supplemental fluorescent light could induce shorter, more compact pepper transplants and 2) to document residual effects of EOD supplemental fluorescent light regulation of pepper transplants on subsequent growth and fruit production after transplanting to the field.

\section{Materials and Methods}

'Keystone Resistant Giant no. 3' pepper is sensitive to subtle changes in light quality (Decoteau et al., 1990) and is a recommended fresh-market cultivar for producers in many areas of the United States. Pepper seeds were planted in the greenhouse on 24 Mar. 1988 and 3 Apr. 1989 in Speedling seedling trays (4.5 $\mathrm{cm}$ cell length, $39.5 \mathrm{~cm}^{2}$ ) (Speedling, Sun City, Fla.) containing Fafard potting mix (Fafard Soilless Peat Mix. no. 3; Fafard, Anderson, S.C.). EOD supplemental fluorescentlight treatments began on 15 Apr. 1988 and 21 Apr. 1989. Supplemental irradiance was sup- plied for $1 \mathrm{~h}$ immediately before sunset each day until transplanting. Light treatments the same as that described for tomato transplants (Decoteau and Friend, 1991) were imposed. The experimental system used 1.2-m-long, cool-white fluorescent bulbs (Workshop F40; Sylvania, Winchester, Ky.) suspended $\approx 0.25$ $\mathrm{m}$ above the seedlings. Supplemental fluorescent light was provided from one bulb in 1988 and from two in 1989. Identical bulbs and fixtures suspended above the seedlings were used in the control treatments, but the bulbs were not illuminated. Two flats (72 plants per flat) were placed under each light treatment.

Supplemental fluorescent light and ambient light conditions were measured with a spectroradiometer (model LI-1800; LI-COR, Lincoln, Neb.) equipped with a remote light collector on a $1.5-\mathrm{m}$ fiber optic probe. The supplemental light from the one-bulb treatment in 1988 and the two-bulb treatment in 1989 was characterized by recording the photosynthetic photon flux (PPF) and estimating phytochrome equilibria (Pfr : Ptot) (Sager et al., 1988) for light $0.25 \mathrm{~m}$ below the light fixtures on a representative day immediately before the light treatments began and thereafter every $10 \mathrm{~min}$ until sunset $\left(<2 \mu \mathrm{mol} \cdot \mathrm{m}^{-2} \cdot \mathrm{s}^{-1}\right)$.

Supplemental fluorescent light treatments were terminated after the EOD treatment on 1 May 1988 and 21 May 1989. Each year five randomly chosen plants from supplemental fluorescent light and control treatments were cut off to measure leaf area, plant height, and plant dry weight. Plant heights were measured from the soil surface to the apical bud, and leaf area was measured using an area meter (LI3100; LI-COR). Dry weight of top growth was determined after oven-drying at 60C for 7 days.

Field plots were established at the Clemson Univ. Calhoun Field Site, Clemson, S.C. In both years, fertilizer was applied to the Congaree silt loam soil (Typic Paleudults) at $\mathrm{N}, \mathrm{P}$, and $\mathrm{K}$, rates of 56,112 , and $112 \mathrm{~kg} \cdot \mathrm{ha}^{-1}$, respectively, before applying the plastic mulch. Black polyethylene mulch $(1.2 \mathrm{~m}$ wide $\times 0.03$ $\mathrm{mm}$ thick), trickle irrigation tubing, and methyl bromide fumigation (at $280 \mathrm{~kg} \cdot \mathrm{ha}^{-1}$ ) were applied by machine on 2 May 1988 and 8 May 1989. The polyethylene mulch beds were 0.8 $\mathrm{m}$ wide $\times 0.1 \mathrm{~m}$ high

Randomly chosen seedlings were transplanted to the field on 25 May 1988 and 22 May 1989. In 1989, the plots did not occupy the same area as in 1988. In-row plant spacing was $0.61 \mathrm{~m}$, and bed centers were spaced 1.8 $\mathrm{m}$ apart. Experimental plots were $6.1 \mathrm{~m}$ long and arranged in a randomized complete-block design with four replications. Recommended cultural practices for pepper production were followed throughout the study (Cook et al., 1982).

Before the first marketable fruit harvest ( 8 July 1988 and 4 Aug. 1989), four contiguous plants at one end of each plot were cut off to measure leaf area, plant height, plant dry weight, fruit count, and fruit weight. Fruit were harvested weekly when they reached marketable size. They were counted, weighed, and graded according to U.S. Dept. of Agriculture (USDA) standards (USDA, 1963). Mar- 
ketable fruit harvest continued for 6 and 7 weeks in 1988 and 1989, respectively. Early yield was the cumulative amount of fruit during the first three harvests each year. All data were tested by analysis of variance to determine significance of treatment effects. Least significance difference values were used for pairwise comparison between treatment means.

\section{Results}

Modifications of the transplant light environment. Supplemental fluorescent light from one bulb increased the PPF in the transplant light environment by $\approx 45 \mu \mathrm{mol} \cdot \mathrm{m}^{-2} \cdot \mathrm{s}^{-1}$ relative to the control (Fig. 1A). One-bulb supplemental light treatment increased the phytochrome equilibrium (Pfr : Ptot) of the transplant light environment by $\approx 0.05$ (Fig. 1B). The supplemental light from the two-bulb treatment in 1989, characterized by Decoteau and Friend (1991), increased the PPF by $\approx 150$ $\mu \mathrm{mol} \cdot \mathrm{m}^{-2} \cdot \mathrm{s}^{-1}$ and increased the Pfr : Ptot by 0.06 compared to the control.

Transplant growth and development. After the last EOD treatment, plants from the one-bulb supplement (Spring 1988) closely resembled those of the control in height and leaf area but had 26\% more biomass (dry weight) (Table 1). Before first fruit harvest, plants exposed to one supplementary bulb while they were seedlings were significantly smaller (28\% shorter, $74 \%$ less leaf area, and $69 \%$ less biomass) than the controls.

After the last EOD treatment, seedlings from the two-bulb supplemental fluorescentlight treatment (Spring 1989) were significantly smaller (16\% shorter, $13 \%$ less leaf area, and $11 \%$ less biomass) than the controls (Table 1). Before first fruit harvest, plants that had been exposed to the two bulbs during transplant production also were significantly smaller (35\% shorter, $79 \%$ less leaf area, and $75 \%$ less biomass) than the controls.

Fruit production and final plant growth. Immediately before the first commercial fruit harvest, there were $55 \%$ and $62 \%$ fewer fruit and $72 \%$ and $79 \%$ less fruit weight from plants that had been in the one-bulb (1988) or the two-bulb (1989) treatments, respectively, than from the controls each year (Table 2). Although the supplemental fluorescent light during transplant production did not affect early or total marketable fruit yield $(P=0.05$, data not presented) compared to controls, there was a large variation within treatments (coefficients of variation for early marketable weight $=40.6$ and 43.1 in 1988 and 1989 evaluations, respectively; coefficients of variation for total marketable weight $=48.9$ and 27.1 in 1988 and 1989 evaluations, respectively).

\section{Discussion}

Because young pepper plants respond to subtle changes in EOD light quality (Decoteau et al., 1990), using light to regulate pepper transplant growth may be a viable alternative to applying chemical growth regulators to generate shorter transplants. Fluorescent light is high in the $\mathrm{R}$ component of the light spec-
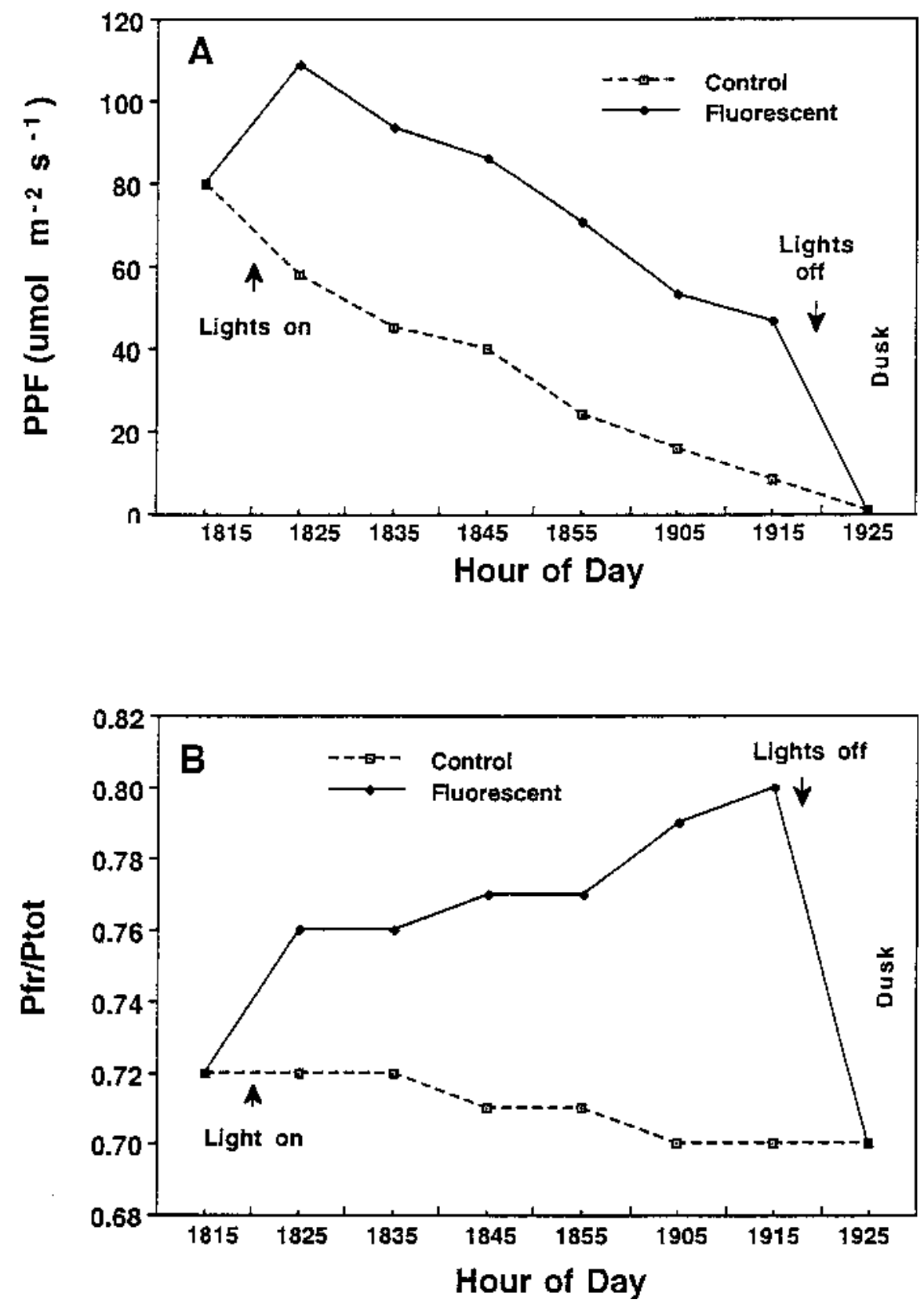

Fig. 1. Influence of $1 \mathrm{~h}$ end-of-day supplemental fluorescent light from one bulb on (A) photosynthetic photon flux (PPF) and (B) Pfr : Ptot of the seedling light environment. Measurements are representative of a typical end-of-day fluorescent light exposure and lack of such light exposure (control). Sunset (dusk) is $<2 \mu \mathrm{mol} \cdot \mathrm{m}^{-2} \cdot \mathrm{s}^{-1}$.

Table 1. Pepper plant growth as affected by end-of-day (EOD) supplemental fluorescent light during transplant production.

\begin{tabular}{|c|c|c|c|c|c|c|}
\hline \multirow[b]{3}{*}{$\begin{array}{l}\text { EOD } \\
\text { light }\end{array}$} & \multicolumn{6}{|c|}{ Sampling period } \\
\hline & \multicolumn{3}{|c|}{ Before transplanting } & \multicolumn{3}{|c|}{ Before first harvest $^{2}$} \\
\hline & $\begin{array}{c}\mathrm{Ht} \\
(\mathrm{cm})\end{array}$ & $\begin{array}{c}\text { Leaf area } \\
\left(\mathrm{cm}^{2}\right)\end{array}$ & $\begin{array}{c}\text { Dry wt } \\
(\mathrm{g})\end{array}$ & $\begin{array}{c}\mathrm{Ht} \\
(\mathrm{cm})\end{array}$ & $\begin{array}{c}\text { Leaf area } \\
\left(\mathrm{cm}^{2}\right)\end{array}$ & $\begin{array}{c}\text { Dry wt } \\
(\mathrm{g})\end{array}$ \\
\hline \multicolumn{7}{|c|}{ Spring 1988} \\
\hline One bulb & 14.2 & 67.2 & 0.39 & 31.9 & 688 & 10.2 \\
\hline None (control) & 14.8 & 63.6 & 0.31 & 44.2 & 2600 & 33.3 \\
\hline Significance & NS & NS & $*$ & $*$ & $*$ & $*$ \\
\hline \multicolumn{7}{|c|}{ Spring 1989} \\
\hline Two bulbs & 12.3 & 99.1 & 0.55 & 30.9 & 1390 & 18.5 \\
\hline None (control) & 14.6 & 114 & 0.62 & 47.5 & 6730 & 75.1 \\
\hline Significance & $*$ & $*$ & $*$ & $*$ & $*$ & $*$ \\
\hline
\end{tabular}

${ }^{2}$ Measured 42 and 72 days after transplanting for 1988 and 1989, respectively.

ss, *Nonsignificant or significant at $P \leq 0.05$, respectively by analysis of variance. 
Table 2. Fruit count and weight on pepper plants before first harvest as affected by end-of-day (EOD) supplemental fluorescent light during transplant production.

\begin{tabular}{|c|c|c|}
\hline \multirow[b]{2}{*}{$\begin{array}{l}\text { EOD } \\
\text { light }\end{array}$} & \multicolumn{2}{|c|}{$\begin{array}{c}\text { Fruit characteristics } \\
\text { before first harvest }\end{array}$} \\
\hline & $\begin{array}{l}\text { No./ } \\
\text { plant }\end{array}$ & $\begin{array}{c}\mathrm{Wt} \\
\text { (g/plant) }\end{array}$ \\
\hline \multicolumn{3}{|c|}{ Spring 1988} \\
\hline One bulb & 2.9 & 27.7 \\
\hline None (control) & 6.5 & 98.2 \\
\hline Significance & $*$ & $*$ \\
\hline \multicolumn{3}{|c|}{ Spring 1989} \\
\hline Two bulbs & 5 & 81.6 \\
\hline None (control) & 13 & 392 \\
\hline Significance & $*$ & $*$ \\
\hline
\end{tabular}

"Significant at $P \leq 0.05$ by analysis of variance.

trum and has been used effectively as a R light source in previous plant photomorphogenesis research (Lockhart, 1964) and as an EOD supplement to reduce tomato transplant height (Decoteau and Friend, 1991).

EOD supplemental fluorescent light from the two-bulb treatment reduced pepper seedling height by $16 \%$. This reduction in seedling height using supplemental fluorescent light is greater than the relative reduction in height reported by Latimer (1991) using single applications of $\beta$-[(4-chlorophenyl)methyl]- $\alpha-(1,1-$ dimethylethyl)-1 $H$-1,2,4-triazole-1-ethanol (paclobutrazol) (20 ppm), butanedioic acid mono(2,2-dimethylhydrazide (daminozide) (5000 ppm), or $\alpha$-cyclopropyl- $\alpha-(4-$ methoxyphenyl)-5-pyrimidinemethanol (ancymidol) (200 ppm) on Impatiens wallerrana Hook. f.; daminozide (5000 ppm) on Zinnia elegans Jacq.; and paclobutrazol (10 ppm) on Tagetes erecta L. Furthermore, none of these plant growth regulators are registered for use on vegetables.

Phytochrome, the R- and FR-sensing pigment in plants, exists in two interconversional forms, Pfr and Pr. When phytochrome is irradiated with $\mathrm{R}$ light, the Pfr form is produced. When phytochrome is irradiated with FR light, the Pr form is produced. In natural or artificial light where R and FR light exist, an equilibrium in the relative amounts of both forms is reached. The relative amount of the these two forms of phytochrome at equilibrium within plant tissue has been correlated with many plant photomorphogenic responses (Cosgrove, 1994). Phytochrome equilibria calculations (e.g., Pfr: Ptot) estimate the projected relative forms of phytochrome in plants in response to specific light environments. Pfr : Ptot is calculated based on spectral photon flux distribution of incident light and photoconversion of phytochrome in vivo (Seyfried and Schafer, 1985) or on a photomorphogenic response such as photosynthetic efficiency (Sager et al., 1988). Pfr : Ptot is the generally accepted measurement for describing photomorphogenic light. In our experiments, supplementing natural EOD sunlight with two fluorescent light bulbs increased the calculated Pfr : Ptot value from $\approx 0.72$ to 0.78 . Ritter et al. (1981) reported the greatest sensitivity of Chenopodium growth to Pfr : Ptot between 0.4 and 0.8 . Values in our study are within this sensitivity range, which may explain the significant growth response of peppers to the relatively small changes in Pfr : Ptot.

Another method to quantify photomorphogenic light is to calculate the relative amount of FR : R light. These values often closely correlate with estimated Pfr : Ptot (Smith, 1982). As estimated in our study, corresponding values of FR : R for Pfr : Ptot ranged from 0.8 for Pfr : Ptot $=0.70$ (control) to 0.2 for Pfr : Ptot $=0.80$ (fluorescent light supplement). Previously, we have shown that height of young pepper plants was affected by as little as a 0.06 difference in FR : $\mathrm{R}$ of upwardly reflected light from various colored plastic mulches (Decoteau et al., 1990). This observation suggests that the light quality modifications with the EOD supplemental fluorescent light that we measured are greater than required to affect early growth of pepper.

The ability of fluorescent light to regulate early pepper seedling development may depend on intensity, because two bulbs, but not one bulb, significantly reduced plant height and leaf area compared to controls when measured before transplanting. Although phytchrome-mediated plant responses generally are considered to be low-intensity responses, Heim and Schafer (1982) have reported intensity-dependent and intensityindependent responses of phytochrome.

Any light quality manipulation during transplant production, regardless of observed effects on seedling development before transplanting to the field, may affect subsequent growth of the pepper plants. Before the first fruit harvest, plants that had been exposed to one supplementary bulb during the seedling stage were significantly smaller (shorter with less leaf area and biomass) than controls, even though growth effects were absent before transplanting. The relative reductions in plant growth obtained with one bulb of supplemental fluorescent light were similar to relative reductions obtained with the two bulbs. These results suggest that subsequent plant growth responses in the field are not as intensitydependent as the growth responses during early seedling growth.

Our use of EOD light quality to regulate pepper transplant development was similar to that previously reported using this system with tomato (Decoteau and Friend, 1991). In that previous study, two bulbs were used, and after the last EOD treatment, tomato transplants were significantly smaller (16\% shorter and $17 \%$ less leaf area) than controls. As measured before first fruit harvest, fluorescent light supplement during transplant production affected early growth of pepper, but not tomato, in the field compared to their respective controls. This observation suggests some differential sensitivity of crop species to EOD supplemental fluorescent light. No residual effect of the supplemental fluorescent light treatments was recorded on marketable fruit production with either pepper or tomato. The large variability in yield within treatments with pepper, as suggested by coefficient of variation values, suggests that future research is needed to verify our observations.
EOD light manipulation can be used to regulate pepper transplant height, and the effect seems to be intensity-dependent. There were residual effects of the EOD fluorescent light treatments on pepper plant growth after transplanting to the field but not on marketable fruit production. Our study with peppers and a previous study with tomatoes (Decoteau and Friend, 1991) strongly suggest that transplant growth regulation using EOD light manipulation may be a low-cost and environmentally safe method of transplant height regulation. Although these results support EOD light regulation of transplant development, more information is needed on the effect of genus, species, and cultivar differences relative to EOD light manipulation on growth and yield before widespread application of these procedures can be recommended and implemented on a commercial scale.

\section{Literature Cited}

Benson, J.L. 1992. Regulation of bedding plant growth and development by spectral filters. MS Thesis, Dept. of Horticulture, Clemson Univ., Clemson, S.C.

Carlson, W.H. 1990. Controlling transplant height. Amer. Veg. Grower 38:16-18.

Cochran, H.L. 1936. Some factors which influence the germination of pepper seeds. Proc. Amer. Soc. Hort. Sci. 33:477-480.

Cosgrove, D.J. 1994. Photomodulation of growth, p. 631-658. In: R.E. Kendricks and G.H.M. Kronenberg (eds.). Photomorphogenesis in plants. 2nd ed. Kluwer Academic Publishers, The Netherlands.

Cook, W.P., R.P. Griffin, and C.E. Drye. 1982. Commercial pepper and eggplant production. Clemson Univ. Coop. Ext. Serv. Hort. Lflt. 35.

Decoteau, D.R. and H.H. Friend. 1991. Growth and subsequent yield of tomatoes following end-of-day light treatment of transplants. HortScience 26:15281530.

Decoteau, D.R., M.J. Kasperbauer, and P.G. Hunt. 1990. Bell pepper plant development over mulches of diverse colors. HortScience 25:460-462.

Hatt, H.A., M.J. McMahon, D.E. Linvil, and D.R Decoteau. 1993. Influence of spectral qualities of mulch film on bell pepper growth and production. Proc. Natl. Agr. Plastics Congr. 4:233-239.

Heim, B. and E. Schafer. 1982. Light-controlled inhibition of hypocotyl growth in Sinapsis alba L. seedlings. Planta 154:150-155.

Latimer, J.G. 1990. Drought or mechanical stress affects broccoli transplant growth and establishment but not yield. HortScience 25:1233-1235.

Latimer, J.G. 1991. Growth retardants affect landscape performance of zinnia, impatiens, and marigold. HortScience 26:557-560.

Lockhart, J.A. 1964. Physiological studies of light sensitive stem growth. Planta 62:97-115.

Moore, J.A. 1989. Speaking of data: The alar controversy. EPA J. 15:5-8

Randle, W.M and S. Honma. 1981. Dormancy in peppers. Scientia Hort. 14:19-25.

Ritter, A., E. Wagner, and E. Schafer. 1981. Light quantity and quality interactions in the control of elongation growth in light-grown Chenopodium rubrum L. seedlings. Planta 153:556-560.

Sager, C., W.O. Smith, J.C. Edwards, and K.L. Cyr 1988. Photosynthetic efficiency and phytochrome equilibria determination using spectral data. Trans. Amer. Soc. Agr. Eng. 31:1882-1887.

Seyfried, M. and E. Schafer. 1985. Action spectra of phytochrome in vivo. Photochem. Photobiol. 42:319-326.

Smith, H. 1982. Light quality, photoreception and plant strategy. Annu. Rev. Plant Physiol. 33:481-518.

U.S. Department of Agriculture. 1963. United States standards for grades of sweet peppers. U.S. Dept. of Agriculture, Agr. Marketing Serv., Washington, D.C. 